УДК 657.421 .3

DOI: https://doi.org/10.26642/jen-2020-1(91)-27-37

Т.О. Завалій, аспірант

Державний університет «Житомирська політехніка»

\title{
Аналітична оцінка кліснтського капіталу світових компаній-лідерів
}

(Представлено: д.е.н., проф. Нестеренко О.О.)

На прикладі звітності про діяльність 100 компаній-лідерів американського фондового ринку досліджено питання наявності та рівня розкриття інформації про нематеріальні активи, щзо характеризують клієнтський капітал. На основі систематизаџї даних звітності ицих компаній визначено види нематеріальних активів, щзо можуть бути інформаційною базою для аналізу клієнтського капіталу. 3 узгодженням вимог міжнародного облікового законодавства прийнято поділяти нематеріальні активи, щуо характеризують клієнтський капітал, на 2 групи - ті, щзо пов'язані із клієнтами (клієнтські списки, клієнтські бази, портфель замовлень тощзо), та ті, щуо пов'язані із маркетингом (торгові марки, торгові найменування, бренди). Визначено частку нематеріальних активів, щзо характеризують клієнтський капітал, як в загальній величині активів компаній-лідерів американського фондового ринку протягом 2014-2018 років, так і нематеріальних активів зокрема. На прикладі результатів 2018 року. встановлено, цьо сировиннопереробні, телекомунікаційні, промислові, технологічні компанії та ті, які виробляють споживчі товари (з переліку 100 компаній-лідерів), демонструють високий рівень частки тих з них, які розкривають інформацію про нематеріальні активи, що характеризують клієнтський капітал, у власній звітності. Визначено динаміку зміни абсолютного середньогалузевого значення нематеріальних активів, щчо характеризують клієнтський капітал, на прикладі досліджуваних компаній за 2014-2018 роки.

Ключові слова: клієнтський капітал; нематеріальні активи; клієнти; відносини із клієнтами; звітність; компанії-лідери американського фондового ринку; ринкова капіталізація.

Актуальність теми. Управління клієнтським капіталом важко уявити без наявності відповідних даних. На жаль, побудова ефективного механізму управління складовими інтелектуального капіталу неможлива через обмеженість даних про відповідні нематеріальні активи у фінансовій звітності вітчизняних підприємств. Зі свого боку, система формування нефінансової звітності знаходиться на етапі становлення та поки не дає можливості аналізувати інформацію про клієнтський капітал українських підприємств. Натомість звітність зарубіжних компаній, що складається відповідно до чинного міжнародного законодавства, демонструє більш прозорий механізм передачі даних, 3 якими можуть ознайомитися всі стейкхолдери компанії та відповідно сформувати власну думку щодо відображених у звітності нематеріальних активів, що характеризують клієнтський капітал.

Аналіз останніх досліджень і публікацій. Питання, присвячені проблематиці аналізу нематеріальних активів підприємств, порушувалися в працях таких вітчизняних дослідників, як Т.М. Банасько [1], О.В. Вакун [2], Ю.А. Гороховець [3], В.М. Диба [4], Я.Р. Мелех [5], М.В. Плекан [6], Т.В. Польова [7], І.Т. Райковська [8], Ю.В. Чуб [9], В.С. Шелест [10] та інших. Такі автори як А.О. Босак, I.В. Прокопенко [11], С.О. Голишева, С.М. Ілляшенко, А.В. Колодка [12] детальнішу увагу зосереджували на проблематиці аналітичних розрахунків, пов'язаних із оцінкою та управлінням клієнтського (споживчого) капіталу підприємства. Відсутність досліджень, присвячених аналітичній оцінці клієнтського капіталу, побудованій на даних звітності, зумовлена обмеженістю розкриття такої інформації в даних звітності українських підприємств. Проблеми обмеженого відображення інтелектуального капіталу та відповідно його структурних елементів (зокрема клієнтського капіталу) в фінансовій та нефінансовій звітностях ставилися в наших попередніх дослідженнях $[13,14]$.

Метою статті $\epsilon$ формування уявлення про необхідність розкриття інформації про клієнтський капітал у звітності українських підприємств на прикладі надання аналітичної оцінки нематеріальним активам, що характеризують клієнтський капітал та відображені у звітності 100 компаній-лідерів американського фондового ринку.

Викладення основного матеріалу дослідження. На сьогодні неможливість проведення аналізу нематеріальних активів, що характеризують клієнтський капітал українських підприємств, спричинена обмеженістю наявної інформаційної бази. У зв'язку з тим, що вітчизняний бухгалтерський облік та відповідно звітність вітчизняних підприємств не створюють необхідного інформаційного забезпечення процесам проведення аналізу нематеріальних активів, що характеризують клієнтський капітал, запропоновано за основу взяти звітні дані зарубіжних компаній.

Механізм складання та оприлюднення звітності зарубіжними компаніями уможливлює створення інформаційної бази для побудови аналітичних розрахунків, спрямованих допомагати формуванню та прийняттю своєчасних ефективних управлінських рішень. Оперативність оприлюднення річних звітів 3 
відповідними показниками результатів діяльності компаній прямо відображається на ступені довіри стейкхолдерів та реакції фондового ринку. Так, наприклад, у день оприлюднення звітності компанії «Amazon.com Inc.» за 2019 р. (31.01.2020 року) ринок миттєво відреагував на представлені звітні дані - за день ринкова капіталізація зросла 3932 млрд дол. до 1000 млрд дол. (рис. 1), що є максимальним значенням для компанії за останні 5 років.

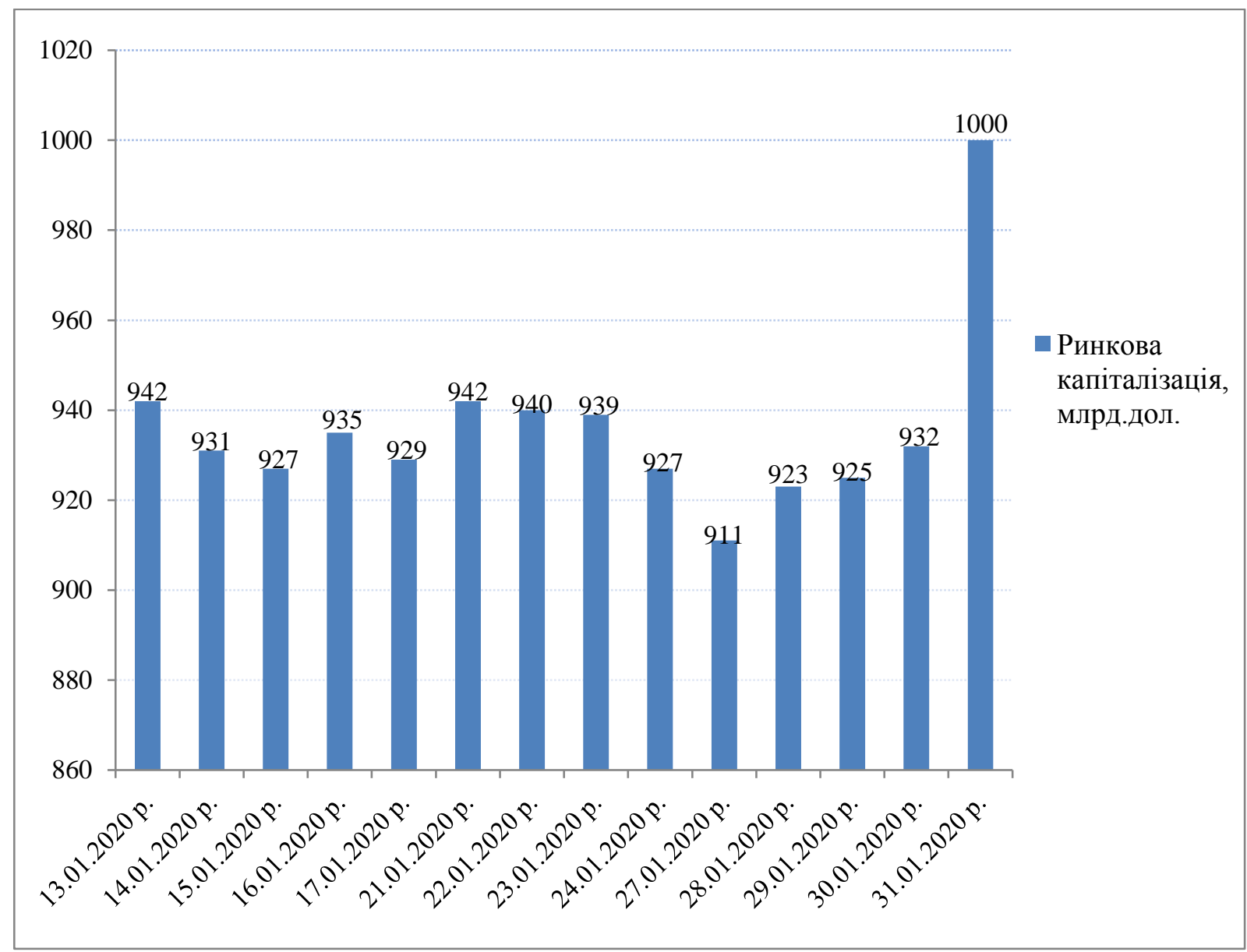

Джерело: побудовано на основі [15]

Рис. 1. Ринкова капіталізація «Атаzоп.com Inc.» протягом 13-31 січня 2020 року, млрд дол.

Блискавична реакція ринку зумовлена представленими показниками, які характеризують результати діяльності «Amazon.com Inc.». Задекларовані результати перевищили очікування експертів, що призвело до досягнення ринкової капіталізації компанії відмітки 1 трильйон дол. Деякі з показників компанії представлені в таблиці 1.

Таблиия 1

Деякі показники, оприлюднені в річній звітності «Атаzоп.сот Inc.» за 2014-2019 роки, млн дол.

\begin{tabular}{|l|c|c|c|c|c|c|}
\hline \multirow{2}{*}{\multicolumn{1}{|c|}{ Показник }} & \multicolumn{7}{c|}{ Рік } \\
\cline { 2 - 7 } & 2014 & 2015 & 2016 & 2017 & 2018 & 2019 \\
\hline Чисті продажі & 88988 & 107006 & 135987 & 177866 & 232887 & 280522 \\
\hline Операційний дохід & 178 & 2233 & 4186 & 4106 & 12421 & 14541 \\
\hline Чистий прибуток (збиток) & -241 & 596 & 2371 & 3033 & 10073 & 11588 \\
\hline Активи, в тому числі & 54505 & 65444 & 83402 & 131310 & 162648 & 225248 \\
\hline - гудвіл & 3319 & 3759 & 3784 & 13350 & 14548 & 14754 \\
\hline $\begin{array}{l}\text { - нематеріальні активи, } \\
\text { в тому числі }\end{array}$ & 764 & 762 & 854 & 3371 & 4110 & 4049 \\
\hline $\begin{array}{l}\text { - нематеріальні активи, } \\
\text { пов'язані із кліснтами }\end{array}$ & 218 & 170 & 117 & 115 & 229 & 152 \\
\hline
\end{tabular}

Фінансові показники «Amazon.com Inc.» за 2019 рік виросли, порівняно з аналогічними за попередній 2018 рік: чисті продажі зросли на 20,45 \%; операційний дохід зріс на 17,07 \%; чистий прибуток зріс на $15,04 \%$ 
Клієнтоорієнтованість є основним вектором для розвитку «Amazon.com Inc.», що підтверджується словами засновника компанії Дж.Безоса: «... Prime-членство продовжує поліпшуватися для клієнтів рік за роком. I клієнти реагують - в цьому кварталі до Рrime приєдналося більше людей, ніж будь-коли раніше, і тепер у нас більше як 150 мільйонів платних членів Prime по всьому світі» [16]. Характеризуючи звітні дані, можна зауважити, що «Amazon.com Inc.» звітується і про нематеріальні активи, пов’язані з клієнтами, що дає змогу провести відповідні аналітичні розрахунки.

Зважаючи на доступність звітної інформації світових компаній, інформаційною базою для дослідження стали дані звітності 100 компаній-лідерів американського фондового ринку. Перелік цих компаній як лідерів американського фондового ринку постійно поновлюється, тому слід зазначити, що для цього дослідження був взятий перелік, який був актуальним на 10.01 .2020 року згідно з даними сайту «Stock Analysis on Net» [17]. Акціями цих 100 компаній-лідерів публічно торгують на біржах США, зокрема на Нью-Йоркській фондовій біржі (New York Stock Exchange, NYSE) та на біржі «NASDAQ» (National Association of Securities Dealers Automated Quotations). Період дослідження звітних даних охоплює 5 років (2014-2018 роки). Для уточнення інформації (наприклад, для розрахунку залишкової вартості досліджуваних активів) додатково використовувалася періодична фінансова звітність компаній і дані інших сайтів, що позиціонуються як провайдери фінансової інформації [18-20].

Звітність компаній складається з узгодженням вимог міжнародних бухгалтерських стандартів, тому й інформація про нематеріальні активи, що характеризують клієнтський капітал, має оприлюднюватися відповідно до регламенту таких документів. Зокрема, відповідно до класифікації МСФЗ 3 «Об’єднання бізнесу» (IFRS 3) [21], нематеріальні активи поділяють на:

- маркетингові нематеріальні активи (з англ. «marketing-related intangible assets»);

- нематеріальні активи, пов’язані з клієнтами (з англ. «customer-related intangible assets»);

- нематеріальні активи, пов'язані з контрактами (з англ. «contract-based intangible assets»);

- нематеріальні активи, пов'язані з технологіями (з англ. «technology-based intangible assets»);

- художні нематеріальні активи (з англ. «artistic-related intangible assets»).

В межах підгрупи маркетингові нематеріальні активи виокремлюються такі складові, як торгові марки, торгові найменування; знаки обслуговування, колективні знаки, сертифікаційні знаки; фірмовий стиль, або зовнішній вигляд (унікальний колір, форма або дизайн пакування); заголовки газет; доменні імена в Інтернеті; договори про неконкуренцію. Зі свого боку, підгрупа нематеріальних активів, пов’язаних із клієнтами, містить списки клієнтів; портфель замовлень; договори із клієнтами та відповідні відносини; позадоговірні відносини із клієнтами. Зважаючи на передбачений в дослідженні підхід до розуміння структури клієнтського капіталу, розроблений відповідно до висновків наших попередніх досліджень $[22]^{1}$, наша увага буде зосереджена на підгрупі нематеріальних активів, пов'язаних із клієнтами, та частково на підгрупі маркетингових нематеріальних активів, а саме на таких їі складових, як торгові марки та торгові найменування.

Аналіз даних 100 компаній-лідерів американського фондового ринку дав змогу систематизувати інформацію про види нематеріальних активів, що характеризують клієнтський капітал, та відповідно відображаються у звітності цих компаній (табл. 2).

Види нематеріальних активів, щзо характеризують клієнтський капітал.

Таблиия 2

аналіз звітності 100 компаній-лідерів американського фондового ринку

\begin{tabular}{|c|c|c|c|}
\hline $\begin{array}{l}\text { № } \\
\text { 3/ח }\end{array}$ & $\begin{array}{c}\text { Види } \\
\text { нематеріальних } \\
\text { активів } \\
\end{array}$ & $\begin{array}{c}\text { Назви мовою } \\
\text { оригіналу } \\
\text { (англійською) } \\
\end{array}$ & Компанії, які розкривають таку інформацію \\
\hline 1 & 2 & 3 & 4 \\
\hline 1 & $\begin{array}{c}\text { Відносини із } \\
\text { клієнтами }\end{array}$ & $\begin{array}{l}\text { Customer } \\
\text { relationships }\end{array}$ & $\begin{array}{l}\text { Adobe Inc.; Allergan PLC; Alphabet Inc.; AT\&T Inc.; Becton, } \\
\text { Dickinson \& Co.; Broadcom Inc.; Caterpillar Inc.; Charter } \\
\text { Communications Inc.; Cisco Systems Inc.; Coca-Cola Co.; Comcast } \\
\text { Corp.; CVS Health Corp.; Danaher Corp.; Emerson Electric Co.; } \\
\text { FedEx Corp.; General Mills Inc.; General Motors Co.; Honeywell } \\
\text { International Inc.; Illinois Tool Works Inc.; Intel Corp.; International } \\
\text { Business Machines Corp.; Intuitive Surgical Inc.; Johnson \& Johnson; } \\
\text { Linde plc; Lockheed Martin Corp.; Procter \& Gamble Co.; Texas } \\
\text { Instruments Inc.; Thermo Fisher Scientific Inc.; Salesforce.com inc.; } \\
\text { Schlumberger Ltd.; Stryker Corp.; United Parcel Service Inc.; United } \\
\text { Technologies Corp.; Walgreens Boots Alliance Inc. }\end{array}$ \\
\hline
\end{tabular}

1 Такий підхід передбачає поділ клієнтського капіталу на чотири складові - інформаційну (СRM-системи, клієнтська база), репутаційну (торговельні марки, комерційні (фірмові) найменування), договірну (портфель замовлень, клієнтела), особистісну (особистісні клієнтські зв'язки). Це зауваження необхідне, адже існують інші підходи до розуміння клієнтського капіталу 
Закінчення табл. 2

\begin{tabular}{|c|c|c|c|}
\hline 1 & 2 & 3 & 4 \\
\hline 2 & Торгові марки & Trademarks & $\begin{array}{l}\text { Adobe Inc.; AT\&T Inc.; Becton; Biogen Inc.; Charter } \\
\text { Communications Inc.; Coca-Cola Co.; Colgate-Palmolive Co.; } \\
\text { CVS Health Corp.; Danaher Corp.; DuPont de Nemours Inc.; Estee } \\
\text { Lauder Cos. Inc.; FedEx Corp.; General Dynamics Corp.; General } \\
\text { Electric Co.; Honeywell International Inc.; Illinois Tool Works } \\
\text { Inc.; International Business Machines Corp.; Johnson \& Johnson; } \\
\text { Kimberly-Clark Corp.; Kraft Heinz Co.; Lockheed Martin Corp.; } \\
\text { Medtronic PLC; Philip Morris International Inc.; Phillips 66; } \\
\text { Starbucks Corp.; Stryker Corp.; T-Mobile US Inc.; United Parcel } \\
\text { Service Inc.; United Technologies Corp.; UnitedHealth Group Inc.; } \\
\text { Walgreens Boots Alliance Inc.; Walt Disney Co.; Zoetis Inc. }\end{array}$ \\
\hline 3 & $\begin{array}{c}\text { Торгові } \\
\text { найменування }\end{array}$ & Trade names & $\begin{array}{l}\text { 3M Co.; Allergan PLC; Alphabet Inc.; AT\&T Inc.; Biogen Inc.; } \\
\text { Boeing Co.; Booking Holdings Inc.; Broadcom Inc.; Comcast } \\
\text { Corp.; Danaher Corp.; Delta Air Lines Inc.; DuPont de Nemours } \\
\text { Inc.; Facebook Inc.; General Dynamics Corp.; Intuit Inc.; Linde } \\
\text { plc; Medtronic PLC; Merck \& Co. Inc.; Phillips 66; Schlumberger } \\
\text { Ltd.; Starbucks Corp.; Thermo Fisher Scientific Inc.; United Parcel } \\
\text { Service Inc.; Walgreens Boots Alliance Inc. }\end{array}$ \\
\hline 4 & $\begin{array}{l}\text { Нематеріальні } \\
\text { активи, } \\
\text { пов'язані із } \\
\text { кліснтами } \\
\end{array}$ & $\begin{array}{l}\text { Customer- } \\
\text { related } \\
\text { intangible } \\
\text { assets }\end{array}$ & $\begin{array}{l}\text { 3M Co; Accenture PLC; Amazon.com Inc.; DuPont de Nemours } \\
\text { Inc.; General Electric Co.; Kraft Heinz Co.; Medtronic PLC; } \\
\text { Microsoft Corporation; Northrop Grumman Corporation; } \\
\text { UnitedHealth Group Inc. }\end{array}$ \\
\hline 5 & Бренди & $\begin{array}{c}\text { Brands, brand } \\
\text { assets }\end{array}$ & $\begin{array}{l}\text { General Mills Inc.; General Motors Co.; Illinois Tool Works Inc.; } \\
\text { Intel Corp.; Linde plc; Marriott International Inc.; PepsiCo Inc.; } \\
\text { Pfizer Inc.; Procter \& Gamble Co.; Zoetis Inc. }\end{array}$ \\
\hline 6 & $\begin{array}{c}\text { Клієнтські } \\
\text { списки }\end{array}$ & Customer lists & $\begin{array}{l}\text { AT\&T Inc.; Automatic Data Processing Inc.; Estée Lauder Cos. } \\
\text { Inc.; Illinois Tool Works Inc.; Intuit Inc.; T-Mobile US Inc.; } \\
\text { Verizon Communications Inc. }\end{array}$ \\
\hline 7 & $\begin{array}{l}\text { Договори із } \\
\text { клієнтами }\end{array}$ & $\begin{array}{l}\text { Customer } \\
\text { contracts }\end{array}$ & Adobe Inc.; Automatic Data Processing Inc.; Broadcom Inc. \\
\hline 8 & $\begin{array}{l}\text { Портфель } \\
\text { замовлень }\end{array}$ & $\begin{array}{l}\text { Order or } \\
\text { production } \\
\text { backlog }\end{array}$ & Adobe Inc.; Broadcom Inc. \\
\hline 9 & $\begin{array}{l}\text { Витрати, } \\
\text { понесені для } \\
\text { отримання } \\
\text { контрактів } \\
\end{array}$ & $\begin{array}{l}\text { Costs incurred } \\
\text { to obtain } \\
\text { contracts with } \\
\text { customers }\end{array}$ & Marriott International Inc. \\
\hline 10 & $\begin{array}{l}\text { Договори } \\
\text { купівлі- } \\
\text { продажу }\end{array}$ & $\begin{array}{l}\text { Purchasing } \\
\text { and payer } \\
\text { contracts }\end{array}$ & Walgreens Boots Alliance Inc. \\
\hline 11 & Клієнтська база & Customer base & Boeing Co. \\
\hline 12 & $\begin{array}{l}\text { Клієнтські } \\
\text { програми }\end{array}$ & $\begin{array}{l}\text { Customer } \\
\text { programs }\end{array}$ & Lockheed Martin Corp. \\
\hline 13 & $\begin{array}{l}\text { Власники } \\
\text { карток } \\
\text { лояльності }\end{array}$ & $\begin{array}{l}\text { Loyalty card } \\
\text { holders }\end{array}$ & Walgreens Boots Alliance Inc. \\
\hline
\end{tabular}

Види нематеріальних активів в таблиці 1 представлені в порядку зменшення кількості компаній: найбільша кількість компаній звітується за такими видами нематеріальних активів, як «Відносини із клієнтами» (34 компанії) та «Торгові марки» (33 компанії). Варто зауважити, що інформація про торгові марки компаній містить інформацію як про такі, що мають визначений, так i про ті, що мають невизначений строк корисного використання.

Виникає необхідність групування нематеріальних активів, що характеризують клієнтський капітал компаній, та інформація про які розкривається у звітності 100 компаній-лідерів американського фондового ринку (табл. 3). 
Групування нематеріальних активів, щзо характеризують клієнтський капітал: аналіз звітності 100 компаній-лідерів американського фондового ринку

\begin{tabular}{|c|c|c|c|}
\hline $\begin{array}{c}\text { Групи } \\
\text { нематеріальних } \\
\text { активів }\end{array}$ & $\begin{array}{c}\text { Назва групи та їі } \\
\text { наповнення відповідно } \\
\text { до МСФЗ } 3 \\
\text { «Об’єднання бізнесу» } \\
\text { в аспекті } \\
\text { характеристики } \\
\text { клієнтського капіталу } \\
\end{array}$ & Складові груп нематеріальних активів & $\begin{array}{c}\text { Частка } \\
\text { компаній, } \\
\text { що } \\
\text { розкривають } \\
\text { таку } \\
\text { інформацію }\end{array}$ \\
\hline \multirow{9}{*}{$\begin{array}{l}\text { Нематеріальні } \\
\text { активи, } \\
\text { пов’язані із } \\
\text { клієнтами }\end{array}$} & \multirow{9}{*}{$\begin{array}{l}\text { Нематеріальні активи, } \\
\text { пов’язані із клієнтами, } \\
\text { містять: } \\
\text { - списки клієнтів; } \\
\text { - портфель замовлень; } \\
\text { - договори з клієнтами } \\
\text { та відповідні } \\
\text { відносини; } \\
\text { - позадоговірні } \\
\text { відносини з клієнтами }\end{array}$} & $\begin{array}{l}\text { Нематеріальні активи, пов'язані із } \\
\text { клієнтами }\end{array}$ & $10 \%$ \\
\hline & & Відносини з клієнтами & $34 \%$ \\
\hline & & Клієнтські списки & $7 \%$ \\
\hline & & $\begin{array}{l}\text { Договори з клієнтами (в т. ч. витрати, } \\
\text { понесені для отримання контрактів, } \\
\text { договори купівлі-продажу) }\end{array}$ & $5 \%$ \\
\hline & & Портфель замовлень & $2 \%$ \\
\hline & & Власники карток лояльності & $1 \%$ \\
\hline & & Клієнтська база & $1 \%$ \\
\hline & & Клієнтські програми & $1 \%$ \\
\hline & & $\begin{array}{l}\text { В цілому (у звітності наявний хоча б один } \\
\text { iз наведених вище видів нематеріальних } \\
\text { активів) }\end{array}$ & $51 \%$ \\
\hline \multirow{4}{*}{$\begin{array}{l}\text { Нематеріальні } \\
\text { активи, } \\
\text { пов’язані із } \\
\text { маркетингом }\end{array}$} & \multirow{4}{*}{$\begin{array}{l}\text { Маркетингові } \\
\text { нематеріальні активи } \\
\text { містять: } \\
\text { - торгові марки, } \\
\text { торгові найменування }\end{array}$} & Торгові марки & $33 \%$ \\
\hline & & Торгові найменування & $24 \%$ \\
\hline & & Бренди & $10 \%$ \\
\hline & & $\begin{array}{l}\text { В цілому (у звітності наявний хоча б один } \\
\text { з наведених вище видів нематеріальних } \\
\text { активів) }\end{array}$ & $54 \%$ \\
\hline \multicolumn{3}{|c|}{ Частка компаній, яка звітує інформацію про нематеріальні активи по 1 та по 2 групі } & $39 \%$ \\
\hline \multicolumn{3}{|c|}{ Частка компаній, яка звітує інформацію про нематеріальні активи по 1 або по 2 групі } & $66 \%$ \\
\hline
\end{tabular}

Узгоджуючи підхід до групування нематеріальних активів, що характеризують клієнтський капітал, 3 чинним міжнародним законодавством, а саме з МСФЗ 3 «Об’єднання бізнесу», такі активи поділяємо на 2 групи - на ті, що пов'язані із клієнтами, та на ті, що пов'язані із маркетингом. 66 компаній зі 100 компанійлідерів американського фондового ринку розкривають у власній звітності інформацію про клієнтський капітал, причому 39 з них звітуються за обома 3 наведених вище груп. Відповідно до даних таблиці 3 , частка компаній, які оприлюднюють інформацію про клієнтський капітал через:

- дані про нематеріальні активи, пов'язані із клієнтами - 51 \%. Такі активи поділяються на ті, що мають позадоговірну основу (списки клієнтів, позадоговірні відносини із клієнтами), та ті, що базуються на вже укладених договорах (портфель замовлень, договори із клієнтами). Наприклад, списки клієнтів містять імена та контактні дані клієнтів, історію їх замовлень, демографічні дані тощо. Зазвичай такі бази даних не регламентуються договорами, хоча можуть орендуватися чи обмінюватися, тому можуть бути відокремленими. Хоча позадоговірні відносини із клієнтами і не регулюються договорами, але все одно можуть бути відокремленими на основі аналогічних обмінних операцій на той самий актив або на аналогічні активи [21];

- дані про нематеріальні активи, пов'язані із маркетингом - 54 \%. Практичний аналіз звітності компаній дав змогу аналізувати інформацію про торгові марки, торгові найменування та бренди. Відсутність бренда в структурі маркетингових нематеріальних активів пояснюється тим, що цей термін використовується як синонім до торгової марки, тому слід зауважити, що МСФ3 3 «Об’єднання бізнесу» не забороняє підприємству визнавати окремим від гудвіла активом групу нематеріальних активів, яку зазвичай називають брендом за умови, що активи, що утворюють цю групу, мають однакові строки корисного використання [21].

Річна звітність 100 компаній-лідерів американського фондового ринку, складена відповідно до вимог міжнародного облікового законодавства, розкриває інформацію щодо клієнтського капіталу через нематеріальні активи, об’єднані у дві групи - ті, що пов'язані з клієнтами, та ті, що пов’язані 3 маркетингом. В аспекті першої підгрупи спостерігаємо у звітах такі складові, як нематеріальні активи, пов’язані з клієнтами (загальна група), відносини з клієнтами, клієнтські списки, договори 3 клієнтами, 
портфель замовлень, власники карток лояльності, клієнтська база, клієнтські програми. В свою чергу, друга підгрупа містить інформацію щодо торгових марок, торгових найменувань та брендів. Саме наведений вище перелік складових двох підгруп може бути інформаційною базою для аналізу клієнтського капіталу компаній.

Вартість взаємовідносин із клієнтами залежить від здатності компанії продавати товари та послуги в майбутньому. Як результат, для того, щоб компанії отримували вартість 3 нематеріальних активів, пов’язаних з клієнтами, вони повинні мати інші активи [23, с. 72]. Тому вважаємо необхідним проведення галузевого аналізу частки нематеріальних активів, які характеризують клієнтський капітал, в загальному обсязі активів компаній та динаміки зміни їх величини протягом 2014-2018 років (табл. 4).

Таблиия 4

Галузевий аналіз динаміки нематеріальних активів, щсо характеризують клієнтський капітал: аналіз звітності 100 компаній-лідерів американського фондового ринку

\begin{tabular}{|c|c|c|c|c|c|c|c|c|c|c|}
\hline \multirow{2}{*}{$\begin{array}{l}\text { № } \\
3 / \Pi\end{array}$} & \multirow{2}{*}{$\begin{array}{c}\text { Специфіка } \\
\text { діяльності } \\
\text { компанії }\end{array}$} & \multirow{2}{*}{$\mathrm{Q}_{\text {заг }}$} & \multirow{2}{*}{$\mathrm{Q}_{\kappa \kappa}$} & \multirow{2}{*}{$\%$ Кк } & \multirow{2}{*}{ Показник } & \multicolumn{5}{|c|}{ Рік } \\
\hline & & & & & & 2014 & 2015 & 2016 & 2017 & 2018 \\
\hline 1 & 2 & 3 & 4 & 5 & 6 & 7 & 8 & 9 & 10 & 11 \\
\hline \multirow{5}{*}{1} & \multirow{5}{*}{$\begin{array}{c}\text { Виробництво } \\
\text { споживчих } \\
\text { товарів }\end{array}$} & \multirow{5}{*}{14} & \multirow{5}{*}{10} & \multirow{5}{*}{71} & $\begin{array}{c}\text { CA, } \\
\text { млн дол. }\end{array}$ & 61623 & 69771 & 72522 & 72500 & 71965 \\
\hline & & & & & $\begin{array}{c}\text { СНА, } \\
\text { млн дол. }\end{array}$ & 8705 & 12852 & 12090 & 11833 & 11256 \\
\hline & & & & & $\begin{array}{c}\text { СКК, } \\
\text { млн дол. }\end{array}$ & 4955 & 4952 & 4666 & 4739 & 4957 \\
\hline & & & & & $\begin{array}{c}\text { Частка СКК } \\
\text { в СНА, \% }\end{array}$ & 56,92 & 38,53 & 38,59 & 40,05 & 44,04 \\
\hline & & & & & $\begin{array}{c}\text { Частка СКК } \\
\text { в СА, \% }\end{array}$ & 8,04 & 7,10 & 6,43 & 6,54 & 6,89 \\
\hline \multirow{5}{*}{2} & \multirow{5}{*}{ Нафта і газ } & \multirow{5}{*}{8} & \multirow{5}{*}{2} & \multirow{5}{*}{25} & $\begin{array}{c}\text { CA, } \\
\text { млн дол. }\end{array}$ & 57823 & 58293 & 64805 & 63179 & 62405 \\
\hline & & & & & $\begin{array}{c}\text { СНА, } \\
\text { млн дол. }\end{array}$ & 2777 & 2738 & 5372 & 5115 & 4798 \\
\hline & & & & & $\begin{array}{c}\text { СКК, } \\
\text { млн дол. }\end{array}$ & 1917 & 1803 & 3483 & 3294 & 3100 \\
\hline & & & & & $\begin{array}{c}\text { Частка СКК } \\
\text { в СНА, \% }\end{array}$ & 69,03 & 65,85 & 64,84 & 64,40 & 64,61 \\
\hline & & & & & $\begin{array}{c}\text { Частка СКК } \\
\text { в СА, \% }\end{array}$ & 3,32 & 3,09 & 5,37 & 5,21 & 4,97 \\
\hline \multirow{5}{*}{3} & \multirow{5}{*}{$\begin{array}{l}\text { Охорона } \\
\text { здоров'я }\end{array}$} & \multirow{5}{*}{20} & \multirow{5}{*}{12} & \multirow{5}{*}{60} & $\begin{array}{c}\text { СА, } \\
\text { млн дол. }\end{array}$ & 56123 & 72737 & 74060 & 77399 & 76808 \\
\hline & & & & & $\begin{array}{c}\text { CНА, } \\
\text { млн дол. }\end{array}$ & 10803 & 18337 & 18643 & 19494 & 17484 \\
\hline & & & & & $\begin{array}{c}\text { СКК, } \\
\text { мЛн дол. }\end{array}$ & 4025 & 4503 & 4740 & 7063 & 6299 \\
\hline & & & & & $\begin{array}{c}\text { Частка СКК } \\
\text { в СНА, \% }\end{array}$ & 37,26 & 24,56 & 25,43 & 36,23 & 36,03 \\
\hline & & & & & $\begin{array}{c}\text { Частка СКК } \\
\text { в СА, \% }\end{array}$ & 7,17 & 6,19 & 6,40 & 9,13 & 8,20 \\
\hline \multirow{5}{*}{4} & \multirow{5}{*}{$\begin{array}{c}\text { Промислові } \\
\text { компанї̈ }\end{array}$} & \multirow{5}{*}{19} & \multirow{5}{*}{16} & \multirow{5}{*}{84} & $\begin{array}{c}\mathrm{CA}, \\
\text { млн дол. }\end{array}$ & 40516 & 41300 & 42544 & 44807 & 49954 \\
\hline & & & & & $\begin{array}{c}\text { СНА, } \\
\text { млн дол. }\end{array}$ & 3340 & 4192 & 4174 & 4467 & 5237 \\
\hline & & & & & $\begin{array}{c}\text { СКК, } \\
\text { млн дол. }\end{array}$ & 2149 & 2640 & 2664 & 2739 & 3378 \\
\hline & & & & & $\begin{array}{c}\text { Частка СКК } \\
\text { в СНА, \% }\end{array}$ & 64,34 & 62,98 & 63,82 & 61,32 & 64,50 \\
\hline & & & & & $\begin{array}{c}\text { Частка СКК } \\
\text { в СА, \% }\end{array}$ & 5,30 & 6,39 & 6,26 & 6,11 & 6,76 \\
\hline
\end{tabular}




\begin{tabular}{|c|c|c|c|c|c|c|c|c|c|c|}
\hline \multicolumn{11}{|c|}{ Закінчення табл. 4} \\
\hline 1 & 2 & 3 & 4 & 5 & 6 & 7 & 8 & 9 & 10 & 11 \\
\hline \multirow{5}{*}{5} & \multirow{5}{*}{ Сировина } & \multirow{5}{*}{2} & \multirow{5}{*}{2} & \multirow{5}{*}{100} & $\begin{array}{c}\text { СА, } \\
\text { млн дол. }\end{array}$ & 44299 & 43173 & 49422 & 106300 & 140708 \\
\hline & & & & & $\begin{array}{c}\text { СНА, } \\
\text { млн дол. }\end{array}$ & 2186 & 2093 & 3305 & 16914 & 23594 \\
\hline & & & & & $\begin{array}{c}\text { СКК, } \\
\text { млн дол. }\end{array}$ & 1177 & 1012 & 1716 & 6802 & 13803 \\
\hline & & & & & $\begin{array}{c}\text { Частка СКК } \\
\text { в СНА, \% }\end{array}$ & 53,84 & 48,35 & 51,92 & 40,22 & 58,50 \\
\hline & & & & & $\begin{array}{c}\text { Частка СКК } \\
\text { в СА, \% }\end{array}$ & 2,66 & 2,34 & 3,47 & 6,40 & 9,81 \\
\hline \multirow{5}{*}{6} & \multirow{5}{*}{$\begin{array}{c}\text { Споживацькі } \\
\text { послуги }\end{array}$} & \multirow{5}{*}{18} & \multirow{5}{*}{10} & \multirow{5}{*}{56} & $\begin{array}{c}\text { CA, } \\
\text { млн дол. }\end{array}$ & 52069 & 61104 & 78172 & 83887 & 105445 \\
\hline & & & & & $\begin{array}{c}\text { СНА, } \\
\text { млн дол. }\end{array}$ & 11142 & 12659 & 20745 & 20852 & 25069 \\
\hline & & & & & $\begin{array}{c}\text { СКК, } \\
\text { млн дол. }\end{array}$ & 2822 & 3277 & 5180 & 4786 & 8230 \\
\hline & & & & & $\begin{array}{c}\text { Частка СКК } \\
\text { в СНА, \% }\end{array}$ & 25,33 & 25,89 & 24,97 & 22,95 & 32,83 \\
\hline & & & & & $\begin{array}{c}\text { Частка СКК } \\
\text { в СА, \% }\end{array}$ & 5,42 & 5,36 & 6,63 & 5,71 & 7,81 \\
\hline \multirow{5}{*}{7} & \multirow{5}{*}{ Телекомунікації } & \multirow{5}{*}{3} & \multirow{5}{*}{3} & \multirow{5}{*}{100} & $\begin{array}{c}\text { СА, } \\
\text { млн дол. }\end{array}$ & 194063 & 236583 & 237964 & 257268 & 289720 \\
\hline & & & & & $\begin{array}{c}\text { СНА, } \\
\text { млн дол. }\end{array}$ & 56952 & 80057 & 79940 & 82841 & 101163 \\
\hline & & & & & $\begin{array}{c}\text { СКК, } \\
\text { млн дол. }\end{array}$ & 779 & 7678 & 6182 & 4793 & 9586 \\
\hline & & & & & $\begin{array}{c}\text { Частка СКК } \\
\text { в СНА, \% }\end{array}$ & 1,37 & 9,59 & 7,73 & 5,79 & 9,48 \\
\hline & & & & & $\begin{array}{c}\text { Частка СКК } \\
\text { в СА, \% }\end{array}$ & 0,40 & 3,25 & 2,60 & 1,86 & 3,31 \\
\hline \multirow{5}{*}{8} & \multirow{5}{*}{ Технології } & \multirow{5}{*}{16} & \multirow{5}{*}{11} & \multirow{5}{*}{69} & $\begin{array}{c}\text { CА, } \\
\text { млн дол. }\end{array}$ & 64698 & 68576 & 79521 & 91780 & 96484 \\
\hline & & & & & $\begin{array}{c}\text { CНА, } \\
\text { млн дол. }\end{array}$ & 3028 & 2528 & 3958 & 4273 & 3944 \\
\hline & & & & & $\begin{array}{c}\text { СКК, } \\
\text { млн дол. }\end{array}$ & 693 & 602 & 818 & 977 & 931 \\
\hline & & & & & $\begin{array}{c}\text { Частка СКК } \\
\text { в СНА, } \%\end{array}$ & 22,89 & 23,81 & 20,67 & 22,86 & 23,61 \\
\hline & & & & & $\begin{array}{c}\text { Частка СКК } \\
\text { в СА, \% }\end{array}$ & 1,07 & 0,88 & 1,03 & 1,06 & 0,96 \\
\hline & В цілому & 100 & 66 & 66 & & & & & & \\
\hline
\end{tabular}

Примітка:

$\mathrm{Q}_{\text {заг }}$ - загальна кількість компаній (в цьому випадку 100 компаній-лідерів американського фондового ринку на дату 10.01 .2020 року); Qкк - кількість компаній, яка звітує інформацію про нематеріальні активи, що характеризують клієнтський капітал;

\%кк- частка компаній, яка звітує інформацію про нематеріальні активи, що характеризують клієнтський капітал, в галузі; СА - середньогалузеве значення активів;

СНА - середньогалузеве значення нематеріальних активів;

СКК - середньогалузеве значення нематеріальних активів, що характеризують клієнтський капітал.

3 урахуванням галузевого поділу варто зазначити, що всі сировиннопереробні та телекомунікаційні компанії, які входять до переліку лідерів, розкривають у власній звітності інформацію про нематеріальні активи, що характеризують клієнтський капітал. Високий відсоток аналогічного розкриття даних спостерігається у промислових компаній - $84 \%$, у виробництві споживчих товарів - 71 \%, у компаній, що належать до технологічних, - 69 \%. Найнижчий показник (25\%) у нафтогазових компаній: тільки 238 нафтогазових компаній-лідерів звітуються про такі нематеріальні активи.

Середньогалузева частка нематеріальних активів, що характеризують клієнтський капітал, не перевищує $10 \%$ від загального розміру активів компаній за усіма досліджуваними галузями. Найвищі показники демонструють компанії, які виробляють споживчі товари (від 6,43 до 8,04 \% від загального значення); компанії, діяльність яких пов’язана з охороною здоров’я (від 6,19 до 9,13 \%); промислові 
компанії (від 5,30 до 6,76\%); компанії, що надають споживацькі послуги (від 5,36 до 7,81 \%). Щодо динаміки частки таких активів у загальному обсязі активів варто зауважити, що явну тенденцію до зростання середньогалузевої частки нематеріальних активів, що характеризують клієнтський капітал, демонструє звітність компаній, що займаються сировиною: якщо у 2014 році це значення становило 2,66 \% від величини загальних активів, то вже у 2018 році воно збільшилося до 9,81 \%. В усіх інших галузях спостерігається нестійка динаміка або до зростання, або до зменшення такого показника.

Для очного розуміння частки нематеріальних активів, що характеризують клієнтський капітал, в загальній структурі активів компаній з різними галузевими особливостями наведемо таке порівняння на прикладі результатів 2018 року (рис. 2).
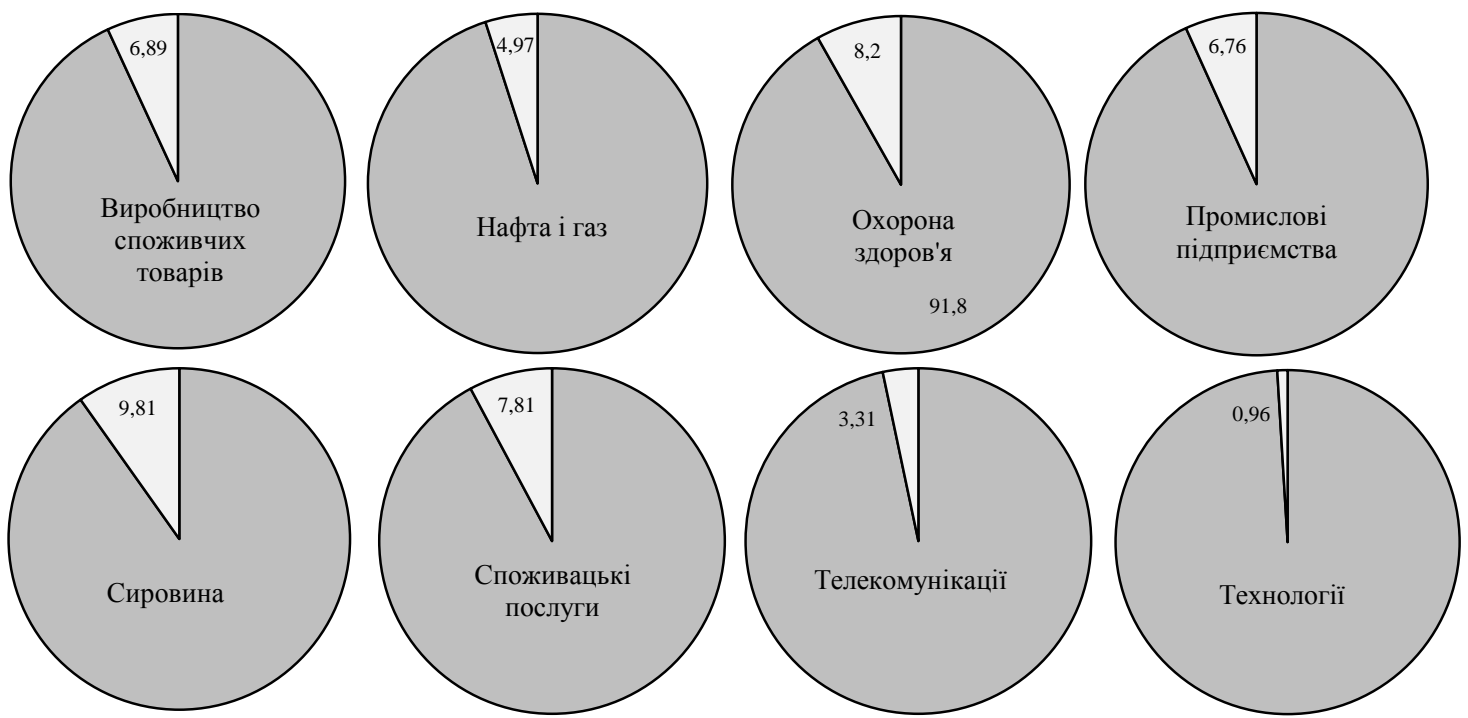

Джерело: за даними звітності 2018 року

Рис. 2. Галузеве порівняння частки нематеріальних активів, щуо характеризують клієнтський капітал, в загальній структурі активів компаній, \%

За результатами діяльності компаній за 2018 рік найбільша питома вага нематеріальних активів, що характеризують клієнтський капітал, спостерігається у сировиннопереробних компаній $(9,81 \%)$, найменше значення - у технологічних компаній $(0,96 \%)$.

Для розуміння частки, яку займають нематеріальні активи, що характеризують клієнтський капітал, в загальному обсязі нематеріальних активів компанії наведемо галузеве порівняння таких показників за 2018 рік (рис. 3).


Джерело: за даними звітності 2018 року

Рис. 3. Галузеве порівняння частки нематеріальних активів, що характеризують клієнтський капітал, в структурі нематеріальних активів компаній, \% 
Найвищий показник частки нематеріальних активів, що характеризують клієнтський капітал, в загальній величині нематеріальних активів спостерігається у звітних даних за 2018 рік у нафтогазових (64,61 \%), промислових $(64,5 \%$ ) та сировиннопереробних компаній $(58,5 \%)$. Тобто, структура нематеріальних активів даних компаній більше ніж на половину складається саме з тих нематеріальних активів, що характеризують клієнтський капітал. Нематеріальні активи, що характеризують клієнтський капітал, компаній інших галузей з представлених займають менше половини загальної величини нематеріальних активів, але це все одно підтверджує важливість розкриття такої інформації. Ці кругові діаграми є доказом «клієнтомісткості» нематеріальних активів безпосередньо тих компаній-лідерів американського фондового ринку, які у власній звітності розкривають інформацію про клієнтський капітал.

Якщо аналіз частки нематеріальних активів, що характеризують клієнтський капітал, дає нам відсоткове уявлення про структурне наповнення такими активами, то необхідним вважаємо також візуалізацію динаміки зміни досліджуваних активів в абсолютному виражені у вигляді графіка (рис. 4).

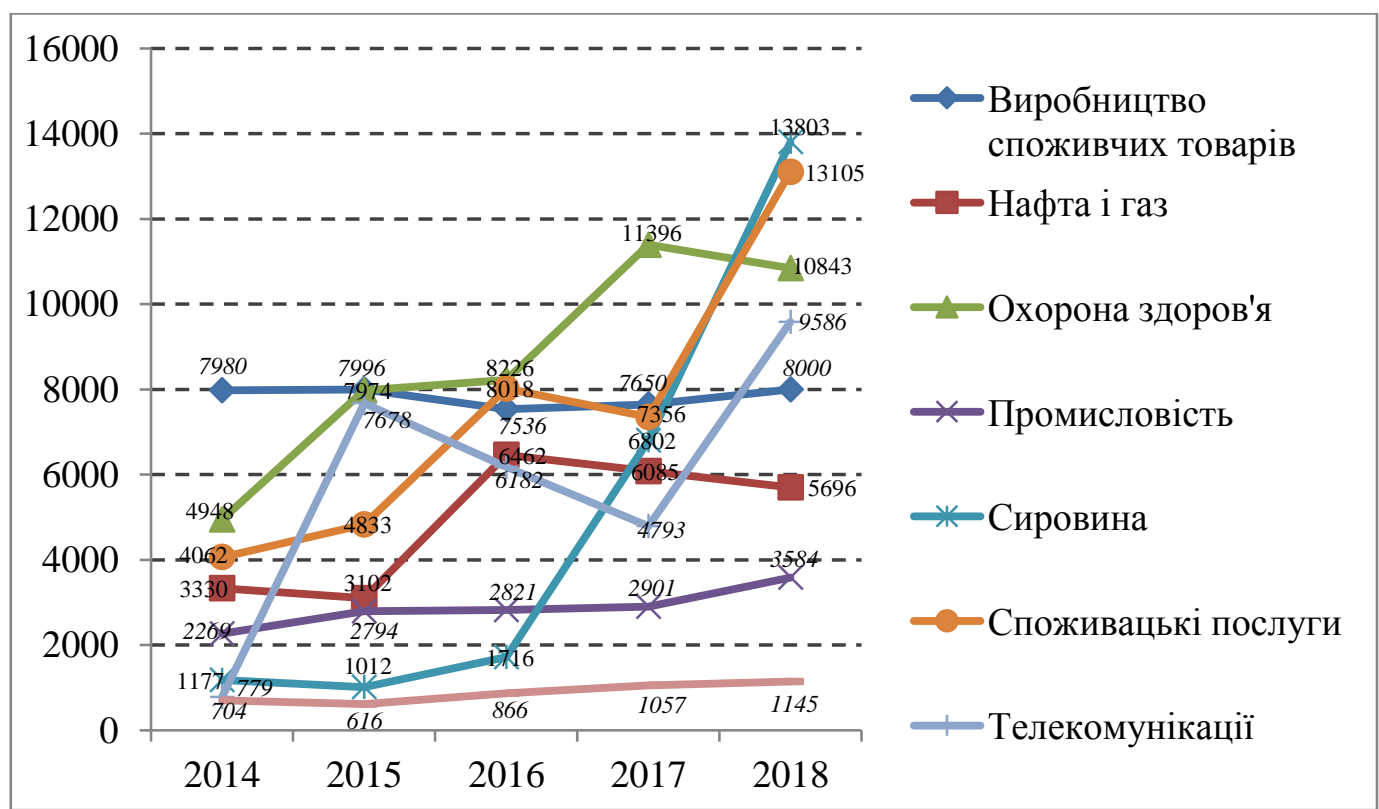

Рис. 4. Графік зміни середньогалузевого значення нематеріальних активів, щуо характеризують клієнтський капітал компаній, за 2014-2018 рр., млн дол.

Абсолютне вираження зміни досліджуваних активів демонструє, що стабільніша ситуація спостерігається у компаніях, які виготовляють споживчі товари, промислових та технологічних компаніях. Саме у цих компаній коливання розміру нематеріальних активів, що характеризують клієнтський капітал, $\epsilon$ незначними протягом досліджуваного періоду. Більш стрімкі зміни до збільшення спостерігаються у сировиннопереробних, телекомунікаційних та компаній, що надають споживацькі послуги, й компанії, щопов'язані з охороною здоров'я, - розмір нематеріальних активів, що характеризують клієнтський капітал цих компаній, зріс у рази за досліджений період (2014-2018 роки).

Важливість наведення таких даних зумовлюється необхідністю побудови ефективного управління клієнтським капіталом як одного з найважливіших драйверів створення вартості в умовах динамічного розвитку бізнесу. Як зазначають Л.Трен і І.Врублевська [23, с. 71], нематеріальні активи, пов'язані 3 клієнтами, створюють вартість протягом обмеженого періоду часу. Без зусиль для постійного зміцнення відносин з клієнтами списки клієнтів з часом знецінюватимуться через смертність клієнтів, наслідки конкуренції чи появу альтернативних товарів і послуг. Крім того, концепція теперішньої вартості ще більше розмиває економічну вигоду від продажу наявним клієнтам у віддаленому майбутньому. В результаті відносини з клієнтами - це активи, економічна вигода яких 3 плином часу зменшується.

Для оцінки ефективності управління клієнтським капіталом необхідна інформаційна база, яка б забезпечувала процеси прийняття управлінських рішень прозорими, оперативними та максимально повними даними. Річна звітність компаній є одним із основних інформаційних джерел для організації управління клієнтським капіталом. Дослідники, які намагаються проаналізувати особливості діяльності українських підприємств, мають чим заповнити прогалину обмеженості та несвоєчасності отримання звітних даних. На жаль, механізми складення та оприлюднення звітності за прикладом досвіду світових компаній-лідерів тільки формуються на вітчизняних теренах, тим самим позбавляючи можливості представити результати аналітичних розрахунків ефективності управління в різних сферах діяльності українських підприємств. 
Висновки та перспективи подальших досліджень. На прикладі звітності про діяльність 100 компаній-лідерів американського фондового ринку досліджено питання складу нематеріальних активів, що характеризують клієнтський капітал, проведено їх групування, виявлено тенденції щодо абсолютної та відносної динаміки їх зміни (на основі середньогалузевих значень) та рівня розкриття такої інформації в межах груп компаній з однаковими галузевими особливостями. Для подальших досліджень питання ефективного управління клієнтським капіталом пропонуємо використовувати такі показники, як частка нематеріальних активів, що характеризують клієнтський капітал, в загальному обсязі нематеріальних активів та, аналогічно, в загальному обсязі активів компанії.

Актуальність проблематики ефективного управління клієнтським капіталом зумовлена визначеними перспективами дослідження в майбутньому. По-перше, з узгодженням вартісно-орієнтованого підходу до управління необхідною $є$ розробка моделі, що підтверджує існування зв'язків між величиною нематеріальних активів, що характеризують клієнтський капітал, та показниками ефективності діяльності (наприклад, ринковою капіталізацією компаніі). По-друге, зважаючи на обмеженість інформаційного забезпечення процесів управління клієнтським капіталом українських підприємств, необхідним є розвиток системи інформування зовнішніх стейкхолдерів (інвесторів, позичальників, аналітиків, громадськості тощо) про клієнтський капітал, зокрема шляхом удосконалення структури Звіту про управління, визначальною особливістю якого $є$ надання нефінансової інформаці і складання якого є обов'язковим для великих і середніх підприємств України, починаючи з 2018 року. По-третє, усвідомлюючи, що ефективність використання клієнтського капіталу залежить від ефективності використання інших капіталів, вважаємо необхідним запропонувати таку управлінську технологію, яка враховувала б показники всіх складових інтелектуального капіталу.

\section{Список використаної літератури:}

1. Банасько Т.М. Економічний аналіз використання нематеріальних активів: значення та методика здійснення / T.М. Банасько // Вісник ЖДТУ. - 2009. - № 4 (50). - С. 6-12.

2. Вакун О.В. Економічний аналіз використання нематеріального капіталу / O.В. Вакун // Проблеми теорії та методології бухгалтерського обліку, контролю і аналізу. - 2012. - Вип. 1 (22). - С. 55-60.

3. Гороховещь Ю.А. Методика економічного аналізу нематеріальних активів: стан і пропозиції / Ю.А. Гороховеиь // БізнесІнформ. - 2018. - № 3. - С. 236-241.

4. Диба В.М. Облік та аналіз нематеріальних активів в умовах інституційних змін: теорія і методологія : дис. ... д.е.н. : спец. 08.00.09 «Бухгалтерський облік, аналіз та аудит» / В.М. Диба - Київ : Київ. нац. екон. ун-т ім. В.Гетьмана - 2017. - $466 \mathrm{c}$.

5. Мелех Я.Р. Облік і аналіз нематеріальних спортивних активів футбольних клубів : автореф. дис. на здобуття наук. ступеня к.е.н. : спец. 08.00.09 «Бухгалтерський облік, аналіз та аудит» / Я.Р. Мелех. - Львів : Львів. торг.-екон. ун-т, 2018. $-21 \mathrm{c}$.

6. Плекан М.В. Облік і аналіз нематеріальних активів в умовах розвитку інформаційної економіки : автореф. дис. на здобуття наук. ступеня к.е.н. : спец. 08.00.09 «Бухгалтерський облік, аналіз та аудит» / М.В. Плекан. Львів : Львів. ком. академія, 2013. - 20 с.

7. Польова T.B. Облік, аудит і аналіз нематеріальних активів: автореф. дис. на здобуття наук. ступеня к.е.н. : спец. 08.06.04 «Бухгалтерський облік, аналіз та аудит» / T.B. Польова. - Харків : Харк. держ. ун-т харчування та торгівлі, 2006. - 19 с.

8. Райковська I.T. Економічний аналіз забезпеченості та ефективності використання нематеріальних активів: методичний підхід / I.T. Райковська // Вісник ЖДТУ. - 2009. - № 1 (47). - С. 108-115.

9. Чуб Ю.В. Аналіз наявності та використання нематеріальних активів / Ю.В. Чуб // Економічний аналіз. 2014. - T. 15, № 3. - C. 225-229.

10. Шелест В.С. Аналітичне забезпечення управління нематеріальними активами / В.C. Шелест // БізнесІнформ. - 2013. - № 11. - С. 329-334.

11. Босак А.О. Концептуальні засади регулювання споживчого капіталу машинобудівних підприємств / А.О. Босак, В.І. Прокопенко // Причорноморські економічні студії. - 2019. - Вип. 38-1. - С. 90-98.

12. Ілляшенко С.М. Управління інтелектуальним капіталом підприємства : монографія / С.М. Ілляшенко, Є.О. Голишева, А.В. Колодка - Суми : ТОВ «Триторія», 2017. - 360 с.

13. Завалій T.O. Інформаційне забезпечення вартісно-орієнтованим управління клієнтським капіталом / T.O. Завалій // Бухгалтерський облік, аналіз, контроль і оподаткування: стан, проблеми та перспективи розвитку : матеріали XIV Всеукр. наук.-прак. конф. здобувачів вищої освіти і молодих учених, 16-17 трав. 2019 р. - Львів : ЛТЕУ, 2019. - С. 28-30.

14. Завалий Т.О. Клиентский капитал в интегрированной отчетности украинских компаний / T.O. Завалий // Экономика и управление: социальный, экономический и инженерный аспекты : сборник науч. статей I межд. науч.-прак. конф., УО Брестский государственный технический университет, г. Брест, 22-23 ноября 2018 г. / Редкол. В.В. Зазерская и др. - Брест : Издательство БрГТУ, 2018. - С. 276-280.

15. Amazon.com Market Cap: 1.013T for Jan. 31, 2020 [Electronic recourse]. - Access mode : https://ycharts.com/companies/AMZN/market_cap.

16. Amazon.com announces fourth quarter sales up $21 \%$ to $\$ 87.4$ billion [Electronic recourse]. - Access mode : https://last10k.com/sec-filings/amzn.

17. Stock Analysis on Net: 100 U.S. Stock Market Leaders [Electronic recourse]. - Access mode : https://www.stock-analysis-on.net.

18. Yahoo Finance [Electronic recourse]. - Access mode : https://finance.yahoo.com/ 
19. The Wall Street Journal [Electronic recourse]. - Access mode : https://www.wsj.com/.

20. MarketWatch [Electronic recourse]. - Access mode : https://www.marketwatch.com/.

21. IFRS 3 Business Combinations. Illustrative Examples Comparison with SFAS 141(R). Table of Concordance (incorporating editorial corrections at 21 January 2008) [Electronic recourse]. - Access mode : https://www.icjce.es/images/pdfs/TECNICA/C02\%20-\%20IASB/C203\%20\%20IFRS\%20y\%20SIC/IFRS\%203\%20Examples\%20y\%20Compar\%20SFAS\%20141\%20\%20-\%20Feb\%202008.pdf.

22. Завалій T.O. Сутність поняття «клієнтський капітал»: підходи та структура. / Т.О. Завалій // Підприємницька модель економіки та управління розвитком підприємства : тези I Міжн. наук.-практ. конф., 8-9 лист. 2018 р. Житомир : ЖДТУ, 2018. - С. 342-346.

23. Tran L.H. Methods for value customer relationships: use of the multi-period excess earnings methods or the distributor method? / L.H. Tran, I.Vrublevskaya // Insights. - 2016, Spring. - Pp. 70-77 [Electronic recourse]. Access mode : http://www.willamette.com/insights_journal/16/spring_2016_10.pdf.

\section{References:}

1. Banasko, T.M. (2009), «Ekonomichnyi analiz vykorystannia nematerialnykh aktyviv: znachennia ta metodyka zdiisnennia», Visnyk ZhDTU, No. 4 (50), pp. 6-12.

2. Vakun, O.V. (2012), «Ekonomichnyi analiz vykorystannia nematerialnoho kapitalu», Problemy teorii ta metodolohii bukhhalterskoho obliku, kontroliu i analizu, Issue 1 (22), pp. 55-60.

3. Horokhovets, Yu.A. (2018), «Metodyka ekonomichnoho analizu nematerialnykh aktyviv: stan i propozytsii», BiznesInform, No. 3, pp. 236-241.

4. Dyba, V.M. (2017), Oblik ta analiz nematerialnykh aktyviv v umovakh instytutsiinykh zmin: teoriia i metodolohiia, D. Sc. Thesis of diss., spec. 08.00.09 Accounting, Analysis and Audit, Kyiv National Economic University, Kyiv, Ukraine.

5. Melekh, Ya.R. (2018), Oblik i analiz nematerialnykh sportyvnykh aktyviv futbolnykh klubiv, Abstract of Diss. k.e.n., spec. 08.00.09 Accounting, Analysis and Audit, Lviv University of Trade and Economics, Lviv, Ukraine.

6. Plekan, M.V. (2013), Oblik i analiz nematerialnykh aktyviv v umovakh rozvytku informatsiinoi ekonomiky, Abstract of Diss. k.e.n., spec. 08.00.09. Accounting, Analysis and Audit, Lviv Academy of Commerce, Lviv, Ukraine.

7. Polova, T.V. (2006), Oblik, audyt $i$ analiz nematerialnykh aktyviv, Abstract of Diss. k.e.n., spec. 08.06.04. Accounting, Analysis and Audit, Kharkiv State University of Food Technology and Trade, Kharkiv, Ukraine.

8. Raikovska, I.T. (2009), «Ekonomichnyi analiz zabezpechenosti ta efektyvnosti vykorystannia nematerialnykh aktyviv: metodychnyi pidkhid», Visnyk ZhDTU, No. 1 (47), pp. 108-115.

9. Chub, Yu.V. (2014), «Analiz naiavnosti ta vykorystannia nematerialnykh aktyviv», Ekonomichnyi analiz, Vol. 15, No. 3, pp. 225-229.

10. Shelest, V.S. (2013), «Analitychne zabezpechennia upravlinnia nematerialnymy aktyvamy», BiznesInform, No. 11, pp. 329-334.

11. Bosak, A.O. and Prokopenko, V.I. (2019), «Kontseptualni zasady rehuliuvannia spozhyvchoho kapitalu mashynobudivnykh pidpryiemstv», Prychornomorski ekonomichni studii, Issue 38-1, pp. 90-98.

12. Illiashenko, S.M., Holysheva, Ye.O., and Kolodka, A.V. (2017), Upravlinnia intelektualnym kapitalom pidpryiemstva, monohrafiia, Trytoriia, Sumy, $360 \mathrm{p}$.

13. Zavalij, T.O. (2019), «Informatsiine zabezpechennia vartisno-oriientovanym upravlinnia kliientskym kapitalom», Bukhhalterskyi oblik, analiz, kontrol i opodatkuvannia: stan, problemy ta perspektyvy rozvytku, materialy XIV Vseukr. nauk.-prak. konf. zdobuvachiv vyshchoi osvity i molodykh uchenykh, LTEU, Lviv, pp. 28-30.

14. Zavalij, T.O. (2018), «Kliyentskiy kapital v integrirovannoy otchetnosti ukrainskikh kompaniy», Ekonomika $i$ upravleniye: sotsialnyy. ekonomicheskiy i inzhenernyy aspekty, sbornik nauch. statey I mezhd. nauch.-prak. konf., Brest State Technical University, Brest, pp. 276-280.

15. Amazon.com Market Cap: 1.013T for Jan. 31, 2020, [Online], available at: https://ycharts.com/companies/AMZN/market_cap

16. Amazon.com announces fourth quarter sales up $21 \%$ to $\$ 87.4$ billion, [Online], available at: $\mathrm{https}: / /$ ast $10 \mathrm{k} . c 0 \mathrm{~m} / \mathrm{sec}-$ filings/amzn

17. Stock Analysis on Net: 100 U.S. Stock Market Leaders, [Online], available at: https://www.stock-analysis-on.net

18. Yahoo Finance, [Online], available at: https://finance.yahoo.com/

19. The Wall Street Journal, [Online], available at: https://www.wsj.com/

20. MarketWatch, [Online], available at: https://www.marketwatch.com/

21. IFRS 3 Business Combinations. Illustrative Examples Comparison with SFAS 141(R). Table of Concordance (incorporating editorial corrections at 21 January 2008), [Online], available at: https://www.icjce.es/images/pdfs/TECNICA/C02\%20\%20IASB/C203\%20-\%20IFRS\%20y\%20SIC/IFRS\%203\%20Examples\%20y\%20Compar\%20SFAS\%20141\%20\%20$\% 20 \mathrm{Feb} \% 202008 . \mathrm{pdf}$

22. Zavalij, T.O. (2018), «Sutnist poniattia «kliientskyi kapital»: pidkhody ta struktura», Pidpryiemnytska model ekonomiky ta upravlinnia rozvytkom pidpryiemstva, tezy I Mizhn. nauk.-prakt. konf., ZhDTU, Zhytomyr, pp. 342-346.

23. Tran, L.H., and Vrublevskaya, I. (2016), «Methods for value customer relationships: use of the multi-period excess earnings methods or the distributor method?», Insights, Spring, pp. 70-77, [Online], available at: http://www.willamette.com/insights_journal/16/spring_2016_10.pdf

Завалій Тетяна Олександрівна - аспірант кафедри менеджменту та підприємництва Державного університету «Житомирська політехніка».

Наукові інтереси:

- проблематика вартісно-орієнтованого управління;

- клієнтський капітал підприємства. 